\title{
DE GRUYTER

\section{IMPLEMENTATION OF GENDER STUDIES RESULTS INTO TEACHER TRAINING IN GERMANY: CHALLENGES AND PERSPECTIVES}

\begin{abstract}
Introduction of gender-specific approaches in education is a new step in the development of pedagogical anthropology. Pedagogy as a fundamental complex discipline, which is based on the latest achievements of knowledge about a human, cannot stand aside the transformational modifications of the societies and cannot help responding to their challenges. Recently, gender studies have become an integral part of pedagogy and gender issues have been available in different areas of teaching. Category of gender, theoretical approaches and empirical results of gender studies represent a challenge to professional training of teachers. In the defined context especially important are the ideas highlighted in the works of some leading contemporary German scholars who have made significant contributions to the establishment and development of gender pedagogy in Germany. The author performs a theoretical analysis of the present state of incorporation of results of gender studies into teachers' training process at German universities; the levels of pedagogical action which these results challenge have been emphasized. Particular attention has been paid to the perspectives of implementation of results of gender studies into professionalism - focused teachers' training on the example of German educational experience. Perspective directions for further studying can be various program models of application of gender studies in organizational and pedagogical foundations, content and teaching methodology.

Key words: professionalism-focused teachers' training in Germany, gender studies, cultural system of gender dichotomy, gender stereotypes, differences and hierarchies.

\section{INTRODUCTION}

Introduction of gender-specific approaches in education is a new step in the development of pedagogical anthropology. At the time when "the humanity's vector to planetary integrity and harmonization" is being formed (Бойко, 2009) and a new system of rules and norms of cultural co-existence of peoples and nations is being created in which a human is perceived as "the measure of all things", there is an urgent need to develop the new methods of cognition of reality which would most adequately meet the requirements of the world's humanistic processes. Pedagogy as a fundamental complex discipline which is based on the latest achievements of knowledge about a human cannot stand aside the transformational modifications of the societies and cannot help responding to their challenges. Therefore, lately there has emerged an increasing interest in methodology of pedagogy, which, according to the statement of the Ukrainian scientist A. Boiko, should be "not only the means of high level of the theoretical cognition, but also the tool for practical transformation of pedagogical reality on the scientific basis" (Бойко, 2009). Today, gender-
\end{abstract}


oriented approach could be considered as such methodological direction of theoretical knowledge and as a practical tool for transformation of education processes.

Nowadays a lot questions concerning the organization of the process of future teachers' professional training are constantly raised in the scientific discussions in Germany, where the issue of its content is the most significant one. To be exact, it sounds like "what knowledge and what competences would enable a future teacher to settle the problems of school education process and would prevent him/her from being stymied by the lack of ability to understand how to solve the task because he/she does not have any knowledge about the problem under consideration".

One of the acute problems that currently raise high waves of scientific debates in Germany is the expediency of the integration of the results of gender research in the process of professionalism - focused teachers' training.

\section{THE AIM OF THE STUDY}

The aim of the article is to analyze the present state of incorporation of results of gender studies into teachers' training in Germany; to identify some features of implementation of results of gender studies into professionalism - focused training of teachers on the example of German educational experience.

\section{THEORETICAL FRAMEWORK AND RESEARCH METHODS}

Gender Mainstreaming as a political strategy, introduced in 1997 by the Amsterdam Treaty, obligates higher education institutions to promote gender equality systematically as a management task in all their organizational processes and areas of activity. The reduction of social but notably gender inequalities in higher education was also incorporated in the final communique of the Berlin Conference of Higher Education Ministers in 2003 (Communique of the Conference of Ministers, 2003). Taking these developments into account, the mainstreaming of gender equality in teaching and learning is of particular importance.

In the defined context especially noteworthy are the ideas highlighted in the works of leading contemporary German scholars who have made significant contributions to the establishment and development of gender pedagogy in Germany, for example, G. Breidenstein, E. Glumpler, S. Grenz, W. Helsper, H. Kelle, B. Kortendiek, M. Kriszio and A. Löther, who raised the issue of gender equality in the education process of higher education; investigators D. Lemmermöhle, B. Liebig, U. Meyerhofer, U. Rabe-Kleberg, E. Rosenkranz-Fallegger, who highlighted the problem of formation of gender competence in higher education institutions; scholars E. Blome, A. Erfmeier, N. Gülcher and K. Smasal, who dedicated their work to the implementation of gender-based management in higher education.

Although at present time gender issues are being embedded within the content of the study of many disciplines in the numerous higher education institutions in Germany and the relevant researches are being conducted, the topic is almost completely underrepresented in the basic sciences of professional teachers' training. It is negligibly presented in the mandatory content of professional disciplines and is not included into the compulsory material for compiling of tests and examinations.

The findings of the current study have been obtained using such research methods as theoretical analysis of historical, philosophical, pedagogical, psychological, methodical literature; systematization and theoretical summarization.

RESULTS

It is difficult to answer the question whether the results of gender research challenge professionalism - focused professional teachers' training, without concentrating 
our attention at the scientific definition of "professional pedagogical action". We apply to the definition performed by German scholars A. Combe, W. Helsper and U. Rabe-Kleberg. Under the professional action in the field of pedagogy they understand the following:

- action based on relevant to this field theoretical knowledge and patterns of interpretation of this knowledge;

- action which does not transfer this knowledge schematically to the concrete action and the individual case but rather keeps in mind the situational context of the individual action and the particularity of the individual case;

- action which takes place under specific historically formed institutional and social conditions;

- action that considers the processes of teaching and learning as interaction;

- action for which inconsistencies and lack of technologies are constitutive, yet this must be justified and responsibility must be assumed (Combe, Helsper, 1996; RabeKleberg, 1996).

The analysis of scientific literature gave us the possibility to distinguish, that the category of gender, theoretical approaches and empirical results of gender studies represent a challenge to the so-defined professional pedagogical action and related to it teachers' training on its (action's) various levels (Glumpler, 1993; Breidenstein, Kelle, 1998; D. Lemmermöhle, 2001). Some of which we would like to highlight. They include:

1. The level of theoretical knowledge and patterns of interpretation.

At this level gender studies require, on the one hand, the new reading of the history of pedagogy, of education and upbringing, of school education and of professional teachers' training in order to reveal the participation of these disciplines in the creation and dissemination of gender differences, gender stereotypes and gender hierarchies, on the other hand, this research is aimed to identify androcentrism of the theoretical approaches, empirical research, pedagogical and didactic concepts that relate to the training of teachers.

Gender studies investigate the importance which the category of gender had in the public discourse in certain times and in certain contexts, the influence of this importance on the social structures and institutions as well as on the individual activities.

If we consider this issue from the point of view of developed in pedagogical discourse, and thus important for professional training of teachers, theoretical knowledge and patterns of interpretation it is easy to recognize that educational theories and related examples of teaching practice were considerably involved into the processes of creating and functioning of a hierarchically structured cultural system of gender dichotomy.

It is well-known that not only J. J. Rousseau developed different educational concepts for Emile and Sophie in the eighteenth century, but gender differences formed the fundamental part of the reflections concerning the theory and practice of educational activities for J. F. Herbart, W. von Humboldt, H. Nohl, J. H. Pestalozzi and other outstanding scientists.

Defining the nature of women as the one, being formed from the three components as a wife, a mother and a housewife, the traditional pedagogy constructed gender differences as anthropological characteristics. "Femininity" was positioned as something "special and polar" and was turned into an object of hoax. It symbolized the subordinated role of women in the gender hierarchy and contributed to limitation of women's access to higher education and participation in the activities of the public sector.

The objective of school was to support the following, as it was considered, natural order: preparing boys for the skilled work outside the house to promote the family's well- 
being, and the education of girls was considered as the preparation of the latter "for their natural profession".

The purpose, organizational forms and the content of schooling as well as the access to general and vocational education were defined in the scientific and educational literature in such a way until the $20^{\text {th }}$ century.

In the middle of the twentieth century the debates about the equality and gender differences were brought to an end for schools of the Eastern Germany by the introduction of "the democratic unified school" in favor of the "recommended" equality. At the same time didactics, teaching methods, guidelines and curricula of the Western Germany often dedicated the sections related to the specific "women's nature" up to the late 1960's. Moreover, at the time when the employment increase of women and young mothers in Germany was no longer possible to ignore, it was noted in the curricula that girls should be provided with education in accordance with their "especially feminine abilities, skills and responsibilities". The peculiarities of "especially masculine skills", however, were not specified because of the orientation on the norm according to which everything in common was considered to be gender-neutral and was constructed with the dominance of masculinity (Lemmermöhle, 2001).

Even this brief review may be sufficient to show that the issue of gender dimension in theoretical knowledge and patterns of interpretation of pedagogical theory and practice has had a long problematic tradition.

The quasi-gender-neutral terms of education, teaching and learning, as well as school and the institutions of teachers' education in their current form can be understood only on the basis of retrospective analysis of the aforesaid tradition (Glumpler, 1993).

In order to facilitate the process of professionalization of teachers' training the constituents of traditional pedagogy, the conditions under which they were formed as well as the gender-encoded history of the proper teaching profession and spheres of professional educational activities must be subjected to severe criticism.

The presence of the category of gender and gender issues in professional, scientific and didactic content of education and the way they will be presented crucially depends on the professional scientific theories, concepts and problems which would be laid into its (content's) basis. According to constructivist knowledge, they control the perception of social reality and - at didactic level - the choice of teaching content and methods.

2. The level of professional action under the conditions of social inequality.

The results of gender studies could be considered as a challenge for the professional pedagogical action and professionalization of teachers as they identify and empirically demonstrate the discrepancy between the democratic rights of equality and actual gender inequality.

At all times, education was meant to overcome the social inequality - whether among individuals, social classes, strata of the population, or among the genders. Greater, better and, above all, equal educational opportunities have been associated with the hope to have equal access to professional activities and related to them social and financial status.

The difference of the development of the interests of boys and girls, which is reflected primarily in evaluation of students' achievements and in the gender-specific career choices as well as the fact that the educational achievements of girls and young women after their transition from school to vocational education or to the sphere of employment are not rewarded in the same way as their male competitors - co-students and co-workers - are still the problems of professional pedagogical action focused on ensuring equal opportunities for both genders. 
Present research results of coeducation show that the entire process of school education in the cultural system of gender dichotomy is not and cannot be gender-neutral. Overall, this research revealed the teachers' closer attention to the boys, though, as it is proved, this fact has not impacted on the better performance of the latter. On the other hand, girls, despite their better school performance, obviously have lower self-esteem and selfconfidence than boys.

Today's discussions concerning coeducation, especially in emotionality with which they are conducted, in a certain way reflect the contradictions and limitations of pedagogical competences focused on the creation of equal society in the existing unequal one and the special attention is drawn to the debate about gender hierarchies, gender identities and the construction of gender in "the contradictory process of modernization".

To facilitate the process of professionalization of teachers' training the contradictions between the cultural system of gender dichotomy which is reflected in school system and the significant changes in the social process of modernization must be subjected to severe criticism. It is necessary to trace the influence and consequences of reproduction of the existing gender structure of society and related gender issues on the students of both genders in the process of school education and be able to evaluate the limitations and opportunities of proper pedagogical action in this process.

3. The level of interactive activities.

Pedagogical activity is defined as an interaction. For this very reason new theoretical approaches to gender studies, such as the theory of "gender construction", i.e. interactive situational and context-related creation of gender, constitute a challenge for the professionalization of teachers.

The latest theoretical approaches to gender studies have revealed that the phenomenon "gender" should be understood not only as a social category, but as a social construction as well. Proceeding from these statements gender, gender differences and gender hierarchies are the products of social practices. Situation- and context-determined construction of these products of social practices is the result of interactive activities.

This point of view is presented in the theoretical debate in the concept of "construction of gender" and draws attention to the process of constructing gender itself, as well as to the future effective mechanisms and regulations of modernization or elimination of gender differences and hierarchies.

By the recourse to interactionistic and ethnomethodological approaches we can reveal that they focus not only on differences between the genders, but on the practices of the differentiation, e.g. in such social institution as school. As it was noted by German researchers G. Breidenstein and $\mathrm{H}$. Kelle, it is important to consider the importance of gender differences in specific situations and in the pedagogical context (Breidenstein, Kelle, 1998).

In order to put on the spotlight the bias and dominant theories, there is a need in inclusion of ethnographic knowledge and development of observation and reflection competences in the process of professional teachers' training, which are unlikely presented in the current teachers' training.

The purpose of these tools is revealing "the best conditions" - whether in coeducation or in single-sex education - for actualization of gender stereotypes, for reproduction and hierarchization or maybe minimization and democratization of gender differences. Professionalism in this context includes the competences to establish the 
learning conditions and learning environments so that they will be oriented both to equality and to the productive handling of differences.

4. The level of uncertainties and inconsistencies of professional pedagogical action.

Professionalism in pedagogic fields of action consists of the subjective competence to justify the actions and take responsibility for them, in spite of the lack of technologies and the antinomies which are constitutive for the pedagogical action.

This subjective competence is especially required when considering gender issues, as the basic principle of our society is the division of people based on their gender, and neither teachers nor students, who are primarily the representatives of a particular gender, cannot but participate in the process of construction of gender differences and hierarchies, even when they are aimed at changes and transformation of existing gender configurations.

Werner Halshper first drew attention to the antinomies and inconsistencies of educational activities, referring to the definition of "technology gap" of pedagogical action given by Luhmann and Schorr (Breidenstein, Kelle, 1998). The contradictions and uncertainties are the constitutive components of professional educational activities which cannot be abolished, that is why can be considered only reflexive (Helsper, 2000). Challenges to the teachers' professionalism are manifested very clearly while studying the possibilities and limitations of pedagogical activities targeted to break the gender stereotypes, differences and hierarchies.

When it comes to breaking of gender stereotypes and gender inequality, the teachers face contradictory tasks: to thematize the gender relations without their dramatizing; to perceive students considering their gender identity, without trying to modify it; to detect rules and mechanisms of manifestation of gender differences and hierarchies and avoid the dangers of their reproduction; to try to minimize the contradictions and to promote mutual understanding between the specific gender groups on the one hand, and at the same time try to avoid being involved in the creation of gender culture and gender hierarchies.

These contradictory tasks challenge the professionalism of teachers in the awareness of their (teachers') own mostly unconscious gender-specific patterns of interpretation, patterns of behavior, beliefs and preferences on the one hand, and in the development of competence to reflect these flaws and effectively eliminate them, on the other hand.

\section{CONCLUSIONS}

General requirements which can be obtained from the analysis of the current state of gender research to gain academic teachers' education can be summarized briefly as follows. Professional academic training of future teachers should necessarily take into account the empirically proven understanding that gender as a social category of human thought and human knowledge occupies its own place in the social and cultural institutions, organizational structures, and gender as a social construction is represented in everyday interactions and scientific discourse. It follows that aimed at the professionalism professional training of teachers should provide future teachers with - knowledge and competencies which would enable them to examine the prevailing theories, issues, concepts - which simultaneously serve as the central didactic reference categories - in order to determine whether and at which angle they represent the category of gender; - the competence to subject to critical analysis existing cultural and social organization forms - one of which is school - in order to reveal whether and how school education and training systems as social institutions in their function and hierarchical structure are involved into the patterns of gender dichotomy culture; - theoretical knowledge, research, observational and other 
methodological competencies in order to detect and effectively balance the processes of constructing gender stereotypes, gender differences and gender hierarchies in school teaching and learning process; - the competence of reflexive analysis and introspection.

The study does not conclude all the aspects of the problem. Perspective directions for further studying can be various program models of application of gender studies in organizational and pedagogical foundations, content and teaching methodology into the process of teachers' training at German universities.

\section{REFERENCES}

1. Breidenstein, G., Kelle, H. (1998). Geschlechteralltag in der Schulklasse. Ethnographische Studie zur Gleichaltrigenkultur [Gender Everyday Life in Class. Ethnographic Study on Peer Culture.] Weinheid/München : Weinheim: Juventa, 287 p. (in German).

2. Combe, A., Helsper, W. (1996). Einleitung: Pädagogische Professionalität. Historische Hypotheken und aktuelle Entwicklungstendenzen [Introduction: Educational Professionalism. Historical Mortgages and Current Trends of Development]. In: Combe, A., Helsper, W. (Hrsg.) Pädagogische Professionalität. Untersuchungen zum Typus pädagogischen Handelns [Pedagogical Professionalism. Investigations of the Type of Pedagogical Action]. Frankfurt a. M., Suhrkamp, pp. 9-48 (in German).

3. Glumpler, E. (1993). Zur Integration von Frauenforschung in die LehrerInnenbildung. Konzeptionen - Cumculumbausteine [To the Integration of Women's Studies in Teachers' Training. Concepts - Curriculum Modules] In: Glumpler, E. (Hrsg.), Erträge der Frauenforschung für die Lehrerlnnenbildung [Profits of Women's Studies for Teachers' Training], Bad Heilbrund/obb., Klinkhardt, pp. 10-37 (in German).

4. Helsper, W. (2000). Antinomien des Lehrerhandelns und die Bedeutung der Fallrekonstruktion - Überlegungen zu einer Professionalisierung im Rahmen universitärer Lehrerausbildung [Antinomies of Teachers Activities and the Importance of the Case Reconstruction - Reflections on Professionalization in the Context of University Teachers' Training]. In: Cloer, E., Klika, D., Kunert, H. (Hrsg.), Welche Lehrer braucht das Land? Notwendige und mögliche Reformen der Lehrerbildung [What kind of Teachers does the Country Need? Necessary and Possible Reforms of Teachers'Training]. Weinheim/München : Juventa, pp. 142-177 (in German).

5. Lemmermöhle, D. (2001). Gender und Genderforschung als Herausforderung für die Professionalisierung von Lehrerinnen und Lehrern [Gender and Gender Research as a Challenge for the Professionalization of Teachers]. In: Beiträge zur Lehrerbildung. Zeitschrift zu Theorie und Praxis der Grundausbildung, Fort- und Weiterbildung von Lehrerinnen und Lehrern in Österreich [Contributions to Teachers' Training. Journal of the Theory and Practice of Basic and Further Education of Teachers in Austria ], No 3, pp. 324-335 (in German).

6. Rabe-Kleberg, U. (1996). Professionalität und Geschlechterverhältnis. Oder: Was ist "semi" an traditionellen Frauenberufen? [ Professionalism and Gender Relations. Or: What is "semi" in Traditional Female Occupations? In: Combe, A., Helsper, W. (Hrsg.), Pädagogische Professionalität. Untersuchungen zum Typus pädagogischen Handelns [Pedagogical Professionalism. Investigations of the Type of Pedagogical Action]. Frankfurt a. M., Suhrkamp, pp. 276-302 (in German).

7. Бойко, А. (2009). Наукові, навчальні й моральні уроки [Scientific, Educational and Moral Lessons. In: Семеновська, Л. А., Хоменко, А. В., Мокляк, В. М. Наукова педагогічна школа [Scientific Pedagogical School]. Полтава : ТОВ «АCMI», 416 p. (in Ukrainian). 